\title{
Efficacy of oral vaccine against bacterial coldwater disease in ayu Plecoglossus altivelis
}

\author{
Motoki Kondo ${ }^{1}$, Kenji Kawai ${ }^{1}$, Masaya Okabe ${ }^{2}$, Nobuyasu Nakano ${ }^{3}$, Syun-ichirou Oshima ${ }^{1, *}$ \\ ${ }^{1}$ Fish Disease Laboratory, Department of Aquaculture, Kochi University, Nankoku, Kochi 783-8502, Japan \\ ${ }^{2}$ Kochi Prefectural Freshwater Fisheries Center, Tosayamada, Kochi 782-0000, Japan \\ ${ }^{3}$ Kochi Freshwater Fisheries Association, Yoshikawa, Kochi 781-5214, Japan
}

\begin{abstract}
The development of a practical vaccination method against bacterial coldwater disease (BCWD) in ayu Plecoglossus altivelis and the efficacy of oral administration of formalin-killed cells (FKCs) of Flavobacterium psychrophilum was investigated. The FKC was administrated at a dose of $0.1-0.2 \mathrm{~g} \mathrm{~kg}^{-1}$ body weight to juvenile ayu ( $0.5 \mathrm{~g}$ body weight) every day for 2 wk or on 5 days over 2 wk. Experimental immersion challenge at 3 and 7 wk after vaccination showed significantly higher survival rates than the controls. The results show the effectiveness of oral vaccination against BCWD in ayu.
\end{abstract}

KEY WORDS: Oral vaccine $\cdot$ Immunization $\cdot$ Ayu $\cdot$ Flavobacterium psychrophilum - Bacterial coldwater disease $\cdot$ BCWD

Resale or republication not permitted

without written consent of the publisher

Flavobacterium psychrophilum, the causal agent of bacterial coldwater disease (BCWD), was first isolated from juvenile coho salmon Oncorhynchus kisutch in the USA in 1948 (Borg 1960). The isolation of F. psychrophilum from ayu Plecoglossus altivelis was reported from cultured and wild fish (Wakabayashi et al. 1994). The bacterium was also isolated from wild pale chub Zacco platypus (Iida \& Mizokami 1996). The bacterium occurs in almost all freshwater areas in Japan, and drug-resistant F. psychrophilum causes serious management problems for fish farmers (Kondo et al. 2001a). To prevent the disease, vaccination by injection has been reported (Obach \& Laurencin 1991, Rahman et al. 2000, LaFrentz et al. 2002). However, vaccinating fish by injection is not practicable because about 1000 t of juvenile ayu are released into Japanese rivers every year, and the fish are sensitive to handling treatment. In this study, the possibility of oral vaccination against $F$. psychrophilum in ayu is investigated.

Materials and methods. Preparation of vaccine: Flavobacterium psychrophilum strain G3724, isolated in 1998 from a diseased ayu in Tokushima Prefecture,
Japan, was used. The bacterium was passed in ayu 3 times to increase the virulence and was stored in $10 \%$ skimmed milk at $-75^{\circ} \mathrm{C}$. The bacterium was cultured in $50 \mathrm{ml}$ modified cytophaga (MCYT) broth $(0.2 \%$ trypton, $0.05 \%$ yeast extract, $0.02 \%$ beef extract, $0.02 \%$ $\mathrm{CH}_{3} \mathrm{COONa}, 0.02 \% \mathrm{CaCl}_{2}$ ) at $15^{\circ} \mathrm{C}$ for $48 \mathrm{~h}$ on a rotary shaker at $100 \mathrm{rpm}$, and then $2.5 \mathrm{ml}$ of the culture was inoculated into $1000 \mathrm{ml}$ MCYT broth in a $2000 \mathrm{ml}$ Sakaguchi-flask, which was incubated at $15^{\circ} \mathrm{C}$ and shaken at $100 \mathrm{rpm}$. The bacteria were cultured to the logarithmic phase, and inactivated at $15^{\circ} \mathrm{C}$ for $48 \mathrm{~h}$ by adding $0.3 \%$ formalin. The formalin-killed bacterial cells (FKC) were harvested by centrifugation at 8000 $g$ for $40 \mathrm{~min}$. The precipitate, including FKC, was resuspended at a concentration of $0.1 \mathrm{~g}$ FKC per $\mathrm{ml}$ of saline containing $0.3 \%$ formalin and was stored at $4{ }^{\circ} \mathrm{C}$.

Fish and vaccination: Test fish, juvenile ayu of an average weight $0.5 \mathrm{~g}$ and $75 \mathrm{~d}$ post-hatching, were provided by a hatchery of the Kochi Freshwater Fisheries Association. Approximately 2000 fish in each group were reared in $2 \mathrm{t}$ tanks $\left(\begin{array}{lll}3.0 & 1.0 & 0.7 \mathrm{~m}\end{array}\right)$ with well-aerated flowing water at 16 to $18^{\circ} \mathrm{C}$. Fish were fed $0.5 \mathrm{~mm}$ commercial dry pellets (Maruha) corresponding to $4 \%$ of the fish body weight $\mathrm{d}^{-1}$ for the entire experiment. Two groups were immunized and another group was used as a non-immunized control. The fish were immunized by feeding the dry pellets mixed with the vaccine at a rate of 0.1 to $0.2 \mathrm{~g}$ FKC per kg fish body weight per day (Fig. 1). Control fish were fed with the dry pellets mixed with sterile physiological saline equal to the volume of vaccine. Group 1 was fed vaccine every day for 2 wk (15 times); Group 2 was fed vaccine on 5 days over 2 wk (Table 1 ).

Challenge test: Challenge tests were done by the immersion infection method at $3 \mathrm{wk}$ (Challenge 1) and $7 \mathrm{wk}$ (Challenge 2) after the immunization. The fish were immersed in aerated well water containing bac- 
Challenge 1 (3 wk after vaccination)
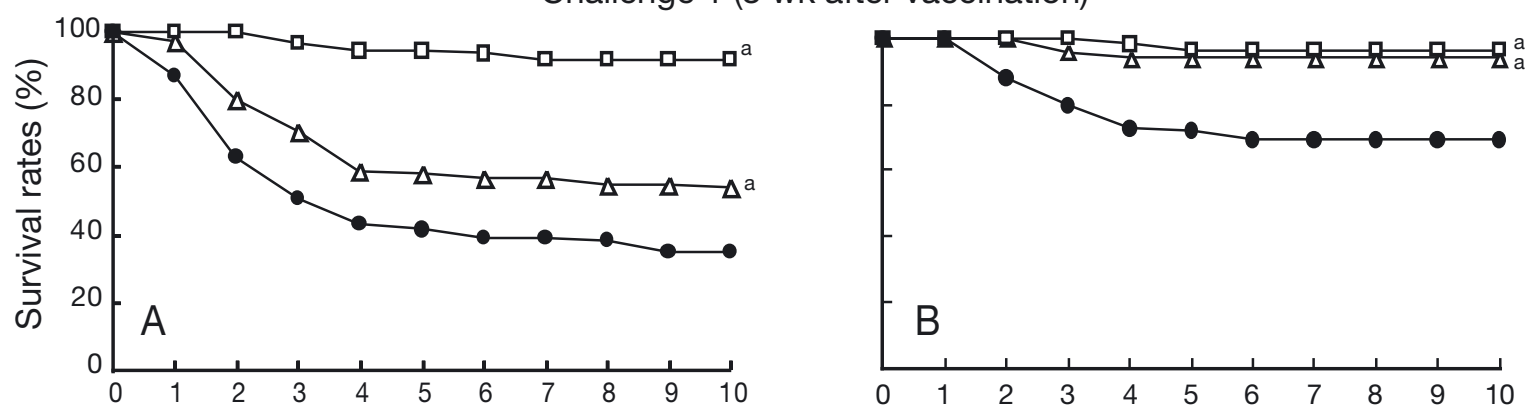

Challenge 2 (7 wk after vaccination)
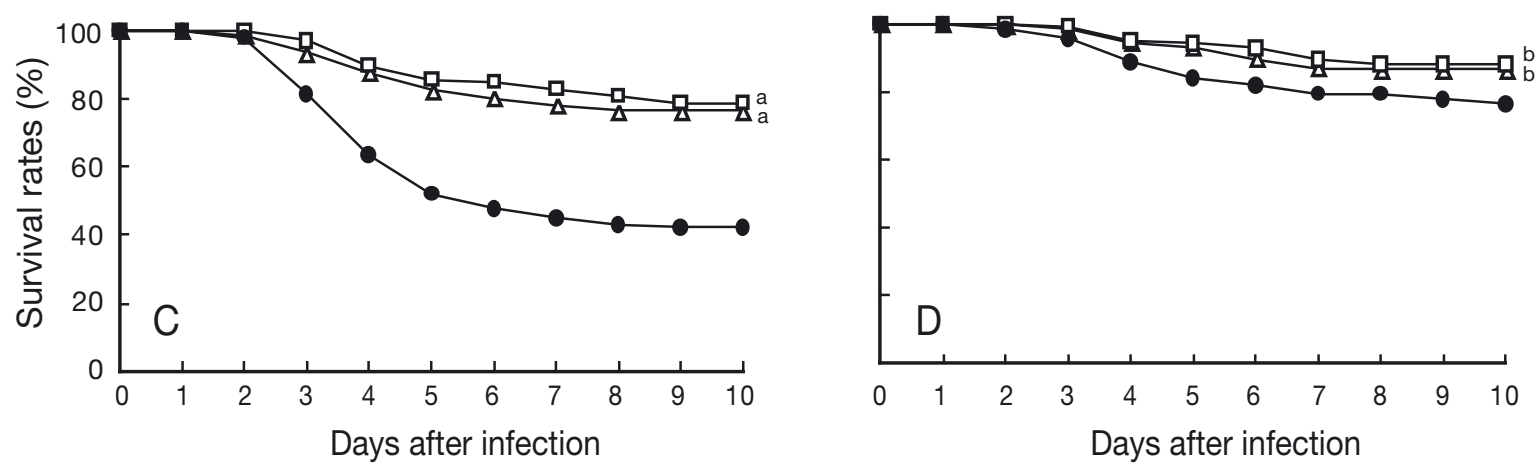

Fig. 2. Plecoglossus altivelis. Changes in the survival rate of ayu immunized by oral administration and challenged by immersion infection. $(\Delta)$ Administered daily; $(\square)$ administered 5 times over $2 \mathrm{wk}_{;}(\bullet)$ control. Challenge doses by immersion were approximately $10^{8} \mathrm{CFU} \mathrm{m} l^{-1}(\mathrm{~A}, \mathrm{C})$ and $10^{7} \mathrm{CFU} \mathrm{ml}^{-1}(\mathrm{~B}, \mathrm{D})$. a : Significant difference $(\mathrm{p}<0.01)$ is shown compared with the value of control group. b: Significant difference $(p<0.05)$ is shown compared with the value of control group

Vibrio anguillarum showed that $\mathrm{LD}_{50}$ doses were the same for immunized and unimmunized fish, and oral vaccination did not increase the protective immune response against bacteria that had already infected the fish. No increase in the agglutination titer occurred in the serum of orally immunized fish, but skin mucus from this group agglutinated the bacteria and inhibited bacterial attachment. Oral vaccination therefore does
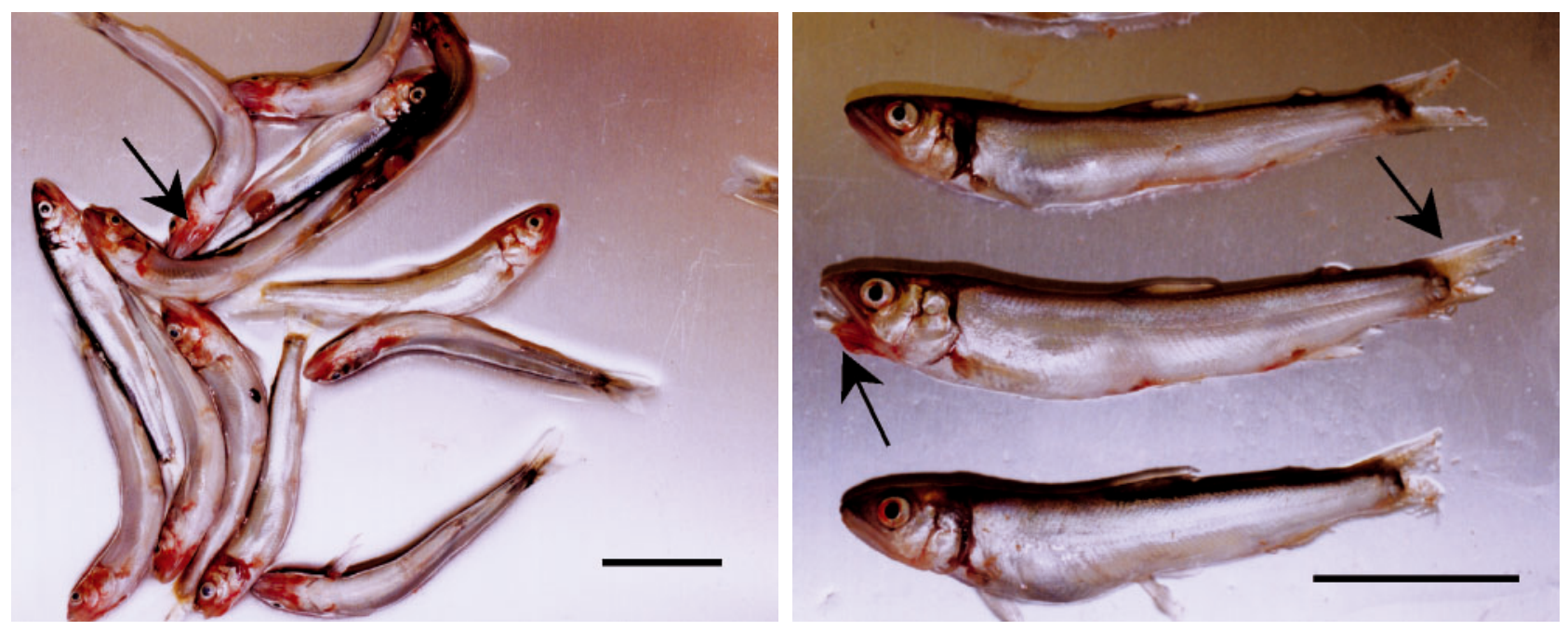

Fig. 3. Plecoglossus altivelis. Typical signs of bacterial coldwater disease (BCWD) in ayu challenged with Flavobacterium psychrophilum by immersion infection. Arrows indicate hemorrhage at the lower part of the operculum and jaw, and partially eroded or lack of caudal fin edge. Scale bar $=2.0 \mathrm{~cm}$ 
not protect against infection, but prevents organisms entering the tissue, inhibiting the attachment and growth of organisms on the body surface of fish. In our experiment, it was unclear whether the protection factor existed in the body-surface mucus of ayu. However, Kondo et al. (2002) showed by electron microscopy that Flavobacterium psychrophilum adhered to infected ayu and invaded the skin at the beginning of infection. Therefore, immersion challenge was adapted for evaluation of the efficacy of oral vaccine in this study. These data indicate that developing an immnune response at the body surface of fish is important.

In this experiment, the logarithmic culture bacteria were used as the antigen for vaccination. Our previous study (Kondo et al. 2001b) showed that this bacterium possessed outer membrane components on the cell surface of the logarithmic phase culture. Rahman et al. (2002) reported the effectiveness of the outer membrane fraction of BCWD. Therefore, interaction between the immune response of the body surface of fish and the bacterial surface structure is important to consider when developing a BCWD vaccine.

Acknowledgements. We wish to thank K. Higuchi, Chairman of Kochi Freshwater Association, for providing experimental fish and facilities. We are also grateful to Dr. H. Wakabayashi for his technical advice.

\section{LITERATURE CITED}

Borg AF (1960) Studies on myxobacteria associated with diseases in salmonid fishes. Wildl Dis 8:1-85

Dunier M, Siwicki AK (1993) Effects of pesticides and other organic pollutants in the aquatic environment on immunity of fish: a review. Fish Shellfish Immunol 3:423-438

Iida Y, Mizokami A (1996) Outbreaks of coldwater disease in wild ayu and pale chub. Fish Pathol 31:157-164

Editorial responsibility: David Bruno,

Aberdeen, Scotland, UK
Joosten PH, Aviles-Trigueros $\mathrm{M}$, Sorgeloos $\mathrm{P}$, Rombout JHWM (1995) Oral vaccination of juvenile carp (Cyprinus carpio) and gilthead seabream (Sparus aurata) with bioencapsulated Vibrio anguillarum bacterin. Fish Shellfish Immunol 5:289-299

Kawai K, Kusuda R, Itami T (1981) Mechanisms of protection in ayu orally vaccinated for Vibriosis. Fish Pathol 15: $257-262$

Kondo M, Kawai K, Jung SJ, Oshima S (2001a) Antimicrobial susceptibility of Flavobacterium psychrophilum isolated from the cultured ayu Plecoglossus altivelis in Japan. J Fish Pathol 14:173-176

Kondo M, Kawai K, Yagyu K, Nakayama K, Kurohara K, Oshima S (2001b) Changes in the cell structure of Flavobacterium psychrophilum with length of culture. Microbiol Immunol 45:813-818

Kondo M, Kawai K, Kurohara K, Oshima S (2002) Adherence of Flavobacterium psychrophilum on the body surface of the ayu Plecoglossus altivelis. Microb Infect 4:279-283

LaFrentz BR, LaPatra SE, Jones GR, Congleton JL, Sun B, Cain KD (2002) Characterization of serum and mucosal antibody responses and relative percent survival in rainbow trout, Oncorhynchus mykiss (Walbaum), following immunization and challenge with Flavobacterium psychrophilum. J Fish Dis 25:703-713

Obach K, Laurencin FB (1991) Vaccination of rainbow trout Oncorhynchus mykiss against the visceral form of coldwater disease. Dis Aquat Org 12:13-15

Patrie-Hanson L, Ainsworth AJ (1999) Humoral immune responses of channel catfish (Ictalurus punctatus) fry and fingerlings exposed to Edwardsiella ictaluri. Fish Shellfish Immunol 9:579-589

Rahman MH, Ototake M, Iida Y, Yokomizo Y, Nakanishi T (2000) Efficacy of oil-adjuvanted vaccine for coldwater disease in ayu, Plecoglossus altivelis. Fish Pathol 35: 199-203

Rahman MH, Kuroda A, Dijkstra JM, Kiryu I, Nakanishi T, Ototake M (2002) The outer membrane fraction of Flavobacterium psychrophilum induces protective immunity in rainbow trout and ayu. Fish Shellfish Immunol 12: 169-180

Wakabayashi H, Toyama T, Iida T (1994) A study on serotyping of Cytophaga psychrophila isolated from fishes in Japan. Fish Pathol 29:101-104

Submitted: January 3, 2003; Accepted: March 7, 2003

Proofs received from author(s): July 17, 2003 